\title{
Therapeutic Levels of Human Protein C in Rats after Retroviral Vector-mediated Hepatic Gene Therapy
}

\author{
Shi-Rong Cai, ${ }^{\star \star \S}$ Susan C. Kennedy, ${ }^{\star \ddagger \S}$ William M. Bowling, $\|$ M. Wayne Flye, $\|$ and Katherine Parker Ponder ${ }^{\star \neq \S}$

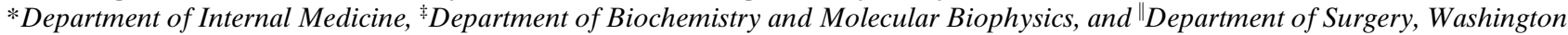 \\ University School of Medicine, St. Louis, Missouri 63110
}

\begin{abstract}
Protein $\mathrm{C}$ deficiency results in a thrombotic disorder that might be treated by expressing a normal human protein $\mathrm{C}$ (hPC) gene in patients. An amphotropic retroviral vector with a liver-specific promoter and the hPC cDNA was delivered to rat hepatocytes in vivo during liver regeneration. Expression of hPC varied from 55 to $203 \mathrm{ng} / \mathrm{ml}(1.3-5.0 \%$ of normal) for $2 \mathrm{wk}$ after transduction. Expression increased to an average of $900 \mathrm{ng} / \mathrm{ml}$ ( $22 \%$ of normal) in some rats and was maintained at stable levels for $1 \mathrm{yr}$. All of these rats developed anti-hPC antibodies and exhibited a prolonged hPC half-life in vivo. The hPC was functional as determined by a chromogenic substrate assay after immunoprecipitation. We conclude that most rats achieved hPC levels that would prevent purpura fulminans, and that hepatic gene therapy might become a viable treatment for patients with severe homozygous hPC deficiency. Anti-hPC antibodies increased the hPC half-life and plasma levels in some rats, but did not interfere with its functional activity. Thus, the development of antibodies against a plasma protein does not necessarily abrogate its biological effect in gene therapy experiments. (J. Clin. Invest. 1998. 101:2831-2841.) Key words: protein C • gene therapy $\bullet$ retroviral vector $\bullet$ liver • antibody
\end{abstract}

\section{Introduction}

Human protein $\mathrm{C}(\mathrm{hPC})^{1}$ is a $62-\mathrm{kD}$ vitamin $\mathrm{K}$-dependent protease that inhibits coagulation. It circulates in blood as a zymogen that is activated by a thrombin:thrombomodulin complex (1). Activated hPC inhibits coagulation by cleaving and inactivating coagulation factors Va and VIIIa (1). As of 1995, 331 mutations of the hPC gene have been described that affect

\footnotetext{
Address correspondence to Katherine Ponder, Department of Internal Medicine, Box 8125, 660 S. Euclid Avenue, St. Louis, MO 63110. Phone: 314-362-5188; FAX: 314-362-8826; E-mail: kponder@imgate. wustl.edu

Received for publication 30 September 1997 and accepted in revised form 25 March 1998.
}

1. Abbreviations used in this paper: DHFR, dihydrofolate reductase; DIC, disseminated intravascular coagulation; hAAT, human $\alpha_{1}$-antitrypsin; hFX, human factor X; hPC, human protein C; HRP, horseradish peroxidase; IRES, internal ribosome entry site; LFABP, liver fatty acid-binding protein; LTR, long terminal repeat; nt, nucleotide.

J. Clin. Invest.

(C) The American Society for Clinical Investigation, Inc. 0021-9738/98/06/2831/11 \$2.00

Volume 101, Number 12, June 1998, 2831-2841

http://www.jci.org the antigenic and/or functional levels (2). Heterozygous hPC deficiency occurs in 1 in 200 and results in $\sim 50 \%$ of normal functional levels of hPC. There is an increased risk of venous thrombosis in adults in some families, although most will never experience a thrombotic episode $(3,4)$. Homozygous hPC deficiency occurs in 1 in 500,000 and results in purpura fulminans, disseminated intravascular coagulation (DIC), or massive venous thrombosis (5-18).

Treatment for homozygous hPC deficiency involves parenteral administration of hPC concentrates (10-14) or anticoagulation with coumadin (15-18). Treatment with hPC concentrates usually requires an indwelling catheter, which carries the risk of infection. The short half-life of hPC, $\sim 10 \mathrm{~h}$ in humans $(11,19-20)$, necessitates administration of concentrates daily or every other day, which will probably be very expensive once they are approved for commercial use. Coumadin therapy requires frequent monitoring and has resulted in thrombosis or hemorrhage during periods of under- or overanticoagulation, respectively $(9,11)$. Thus, although existing treatments for homozygous hPC deficiency can prolong life, they are expensive, require close medical attention, and the patients are still at risk for severe adverse effects.

Gene therapy involves transfer of a gene that encodes a functional protein into the appropriate cells of a patient with a genetic deficiency. Gene therapy might permanently correct the clinical manifestations of hPC deficiency by achieving continuous production of hPC. Liver is the optimal target organ because it is the major site of hPC synthesis and it has direct contact with the blood. Liver transplantation resulted in resolution of the thrombotic tendency in one patient with severe hPC deficiency (9). Gene therapy for other proteins involved in blood coagulation has been attempted by delivering plasmid DNA or viral vectors to various cell types using ex vivo or in vivo methods (21-24). Delivery of adenoviral vectors or plasmid DNA to the livers of mice, rats, or dogs has resulted in therapeutic levels of factor VIII (25-27) or factor IX (28-32), but levels declined rapidly in normal animals. Immunosuppression (28) or tolerization by injection of adenoviral vector at birth (31) slowed but did not prevent the decline in expression in most animals. Although integrated plasmid DNA resulted in therapeutic levels of expression of factor IX from myoblasts in mice, the procedure led to the development of a fibrosarcoma in one animal (33). Retroviral vectors have resulted in long-term but subtherapeutic levels of expression of factor IX from hepatocytes (34) or myoblasts (35) in vivo. In contrast, utilization of the strong liver-specific human $\alpha_{1}$-antitrypsin (hAAT) promoter led to therapeutic levels of expression of functional human factor $\mathrm{X}(\mathrm{hFX})$ from the liver in rats for at least $1 \mathrm{yr}$ (36). More recently, adenovirus associated virus (AAV) vectors have resulted in therapeutic levels of expression of factor IX from muscle (37) or liver (38) in mice, although it takes 2 mo after gene transfer for these levels to be achieved.

We demonstrate here that a retroviral vector with an hPC 
cDNA and the strong liver-specific hAAT promoter can result in therapeutic levels of expression of hPC in rats. We also demonstrate that some normal rats develop antibodies against $\mathrm{hPC}$ that prolong the half-life of the protein in blood, but do not interfere with its functional activity.

\section{Methods}

Construction of retroviral vectors. A complete hPC cDNA (39) was modified to contain a consensus translational initiation sequence by digestion with NotI (cuts $5^{\prime}$ to hPC in the vector) and BalI (cuts 35 nucleotides [nt] downstream of the translational initiation site) and ligation with the following annealed oligonucleotides: 5'-GGCCGCAAGCTTGCCGCCACCATGTGGCAGCTCACAAGCCTCCTGCTGTTCGTGG-3' (top strand) and 5'-CCACGAACAGCAGGAGGCTTGTGAGCTGCCACATGGTGGCGGCAAGCTTGC$3^{\prime}$ (bottom strand). This results in a NotI site that is $21 \mathrm{nt}$ upstream of the translational initiation site. The DNA was sequenced to confirm that it contained the correct sequence. The PstI site located $14 \mathrm{nt}$ downstream of the stop codon was converted to an EagI site. The plasmid containing the modified 1.4-kb hPC cDNA was designated hPCK-280.

hPC-701 contains the ApoE enhancer, the hAAT promoter, the hPC cDNA, and the internal ribosome entry site (IRES)-dihydrofolate reductase (DHFR) cassette. It was created by digesting ApoEhAAT-LTR (40) with NotI, and replacing the hAAT cDNA with the modified hPC cDNA obtained from hPC-K-280. hPC-702 contains the ApoE enhancer, hAAT promoter, and the hPC cDNA without the IRES-DHFR cassette. It was created by digestion of LTR-FX (36) with XhoI, which cuts just downstream of the DHFR gene (position 2937 of LNL-6 [41]), followed by blunt-end formation with T4 DNA polymerase, and ligation with XbaI linkers (CTCTAGAG). After XbaI digestion (cuts just upstream of the internal ribosome entry site sequence and in the middle of the $3^{\prime}$ long terminal repeat [LTR]) the 6-kb fragment (containing the $5^{\prime}$ LTR and the hFX gene) and the 550-bp fragment (containing the $3^{\prime}$ LTR) were isolated and religated to generate $\mathrm{hFX}-515$. The hAAT promoter $(-347$ to +56$)$ was cloned into the BglII site of hFX-515 as described (42) to create hFX-517. A 650-bp BamHI/BglII fragment containing four copies of the 156-bp apolipoprotein $\mathrm{E}$ enhancer was cloned upstream of the hAAT promoter as described (40) and the factor X cDNA was removed by NotI restriction and replaced with the $1.4-\mathrm{kb}$ modified hPC cDNA obtained after Nott/EagI restriction of hPC-K-280 to create hPC-702.

Generation of the retroviral vector packaging cell lines. The amphotropic GP+envAM12 (43) and NIH 3 T3 murine fibroblast (44) cells were maintained as described previously (45) in high glucose DMEM containing $10 \%$ heat-inactivated supplemented calf serum (Hyclone Laboratories, Logan, UT), penicillin $\left(10^{5} \mathrm{U} / \mathrm{liter}\right)$, streptomycin $\left(10^{5} \mu \mathrm{g} / \mathrm{liter}\right.$ ), and $10 \mu \mathrm{g} / \mathrm{ml}$ vitamin $\mathrm{K}$ (Sigma Chemical Co., St. Louis, MO). $9 \mu \mathrm{g}$ of hPC-701 or hPC-702 was cotransfected with $1 \mu \mathrm{g}$ of PGK-neo (46) into GP+envAM12 cells using calcium phosphatemediated transfection (41), and clones were selected with $0.5 \mu \mathrm{g} / \mathrm{ml}$ of G418 (Gibco/BRL, Rockville, MD). Colonies were picked, and three rounds of screening were performed to identify four colonies that conferred the highest level of expression of hPC upon NIH 3T3 cells. To quantitate the expression of hPC in singly transduced cells, NIH 3 T3 cells were transduced with hPC-701 at a low multiplicity of infection, and methotrexate-resistant $\left(\mathrm{Mtx}^{\mathrm{R}}\right)$ cells were selected with $250 \mathrm{nM}$ Mtx. A pool of 50-100 colonies was grown to confluence, washed three times with PBS, then incubated with $5 \mathrm{ml}$ of DMEM with $10 \mathrm{mM}$ Hepes $\mathrm{pH} 7.4$ and vitamin $\mathrm{K}$, but without serum, for $6 \mathrm{~h}$. The supernatant was collected and assayed for hPC functional and antigenic levels.

hPC ELISA. ELISA plates were coated for $2 \mathrm{~h}$ at $37^{\circ} \mathrm{C}$ with 100 $\mu \mathrm{l}$ of a 1:100 dilution of polyclonal goat anti-hPC antibody (catalog \#241; American Diagnostica Inc., Greenwich, CT) as described (47), washed three times with $200 \mu \mathrm{l}$ of $100 \mathrm{mM} \mathrm{NaCl}, 50 \mathrm{mM}$ Tris[hydroxymethyl]amino-methane- $\mathrm{HCl} \mathrm{pH} 7.5$ (TBS), and blocked overnight at $4^{\circ} \mathrm{C}$ with $200 \mu \mathrm{l}$ of TBS with $5 \%$ dry nonfat milk (Schnuck's Grocery, St. Louis, MO) (TBS-milk). Samples or standards containing $100 \mu \mathrm{l}$ were incubated at $37^{\circ} \mathrm{C}$ for $2 \mathrm{~h}$ and washed six times with TBS- $0.05 \%$ Tween 20 . The same anti-hPC antibody was coupled to horseradish peroxidase (HRP) with $N$-succinimidyl $S$-acetylthioacetate using a kit from Pierce (Rockford, IL), and $100 \mu$ l of TBS-milk containing this HRP-coupled antibody at a 1:500 dilution was incubated at $37^{\circ} \mathrm{C}$ for $2 \mathrm{~h}$. The plates were washed six times with $200 \mu \mathrm{l}$ of TBS- $0.05 \%$ Tween 20 and the OD at $450 \mathrm{~nm}$ observed after the addition of 3,3',5,5'-tetramethylbenzidine dihydrochloride (47). hPC standards were generated by diluting a pool of normal human plasma and assuming a concentration of $4 \mu \mathrm{g} / \mathrm{ml}$. Experimental samples were diluted to give a value that fell within the linear range of the standard curve. All rat samples obtained at 10 mo or earlier after transduction were analyzed in the same ELISA. Samples obtained at later timepoints were analyzed in a separate assay using different aliquots from the same set of standards.

Protein C chromogenic substrate assay. To determine the hPC functional activity, $150 \mu \mathrm{l}$ of the conditioned medium from singly transduced NIH 3 T3 cells was mixed with $50 \mu \mathrm{l}$ of TBS in an ELISA plate well and the $\mathrm{hPC}$ was activated at $25^{\circ} \mathrm{C}$ for $10 \mathrm{~min}$ with $2 \mathrm{U}$ of Protac (American Diagnostica, Inc.), which is an activator of protein $\mathrm{C}$ derived from the venom of the copperhead snake Agkistrodon contortrix. hPC chromogenic substrate (Spectrozyme PCa; American Diagnostica, Inc.) was added at $100 \mu \mathrm{M}$ final concentration, and the OD measured 1-2 $\mathrm{h}$ later at $405 \mathrm{~nm}$; the OD observed immediately after the addition of substrate was subtracted from each sample. Blanks contained $50 \mu \mathrm{l}$ of TBS and $150 \mu \mathrm{l}$ of medium. Conditioned medium from nontransduced NIH 3T3 cells did not have any hPC activity. A standard curve was created by adding 20 to $1.25 \mu$ of human plasma (George King Biomedicals, Overland Park, KS), 30-48.75 $\mu$ l of TBS, and $150 \mu \mathrm{l}$ of medium, and observing the change in OD after the addition of Protac and hPC chromogenic substrate.

In vivo transduction of rat hepatocytes. Adult male Lewis rats (Sprague Dawley, Indianapolis, IN) weighing $\sim 200$ grams received standard institutional care. $12 \mathrm{ml}$ of conditioned medium was collected from each of 24 confluent $15-\mathrm{cm}$ plates of packaging cells grown at $32^{\circ} \mathrm{C} \mathrm{(48)}$ and concentrated by ultracentrifugation (45). The pellets were suspended in medium with $8 \mu \mathrm{g} / \mathrm{ml}$ polybrene, and injected without inflow occlusion into the portal vein of a rat that received a $70 \%$ hepatectomy $24 \mathrm{~h}$ previously (45). Retroorbital blood was anticoagulated with a $1 / 10$ volume of $3.8 \%$ trisodium citrate.

hPC half-life study. Purified hPC obtained from human plasma was generously provided by Dr. J. Miletich. $16 \mu \mathrm{g}$ of hPC was iodinated with $250 \mu \mathrm{Ci}$ of I ${ }^{125}$ and IODO-GEN (Pierce, Rockford, IL) to a specific activity of $3.7 \times 10^{7} \mathrm{cpm} / \mu \mathrm{g}$ according to the instructions of the manufacturer. $6 \times 10^{7} \mathrm{cpm}$ of radiolabeled $\mathrm{hPC}$ was injected into the penile vein of each rat, and plasma was collected at $1 \mathrm{~h}$ or later. $0.5 \mu$ l of plasma was electrophoresed on a nonreducing sodium dodecylsulphate $8 \%$ polyacrylamide gel (49), the gel was dried, and the hPC band was quantitated by using a STORM PhosphorImager.

ELISA for anti-hPC antibodies. ELISA plates were coated with $100 \mu \mathrm{l}$ containing $1 \mu \mathrm{g} / \mathrm{ml}$ of $\mathrm{hPC}$ in $0.1 \mathrm{M}$ sodium bicarbonate $\mathrm{pH}$ 9.5, then blocked with TBS-milk. Plasma samples were diluted at $\geq 1: 100$ in TBS-milk and incubated on the plates for $2 \mathrm{~h}$ at $25^{\circ} \mathrm{C}$ and washed six times with TBS- $0.05 \%$ Tween 20 . An affinity purified goat anti-rat IgG antibody (Organon Teknika Corp., Durham, NC) coupled to HRP was added at a 1:1,000 dilution, the washed plate was developed with 3,3',5,5'-tetramethylbenzidine dihydrochloride, and the OD was read at $450 \mathrm{~nm}$ (47). Initial experiments demonstrated that all pretransduction plasma samples had a low activity in the anti-hPC antibody assay when tested at a 1:100 dilution, while most samples had detectable activity above background when assayed at a 1:50 dilution. We therefore tested all posttransduction samples at a 1:100 dilution, and performed serial dilutions if the initial value was positive. Samples were considered positive if the OD was at least twice as high 
as that observed in the 1:100 dilution of the pretreatment sample for that rat.

hPC immunoprecipitation/functional assay. For each sample, 20 $\mu 1$ of Protein G Sepharose 4 Fast Flow (Pharmacia LKB Biotechnology, Piscataway, $\mathrm{NJ}$ ) was incubated for $2 \mathrm{~h}$ at $25^{\circ} \mathrm{C}$ with $5 \mu \mathrm{l}$ of goat anti-hPC antibody. The beads were spun for $2 \mathrm{~min}$ at $500 \mathrm{~g}$ and washed six times with $1 \mathrm{ml}$ of TBS- $0.05 \%$ Tween 20 per sample, once with $1 \mathrm{ml}$ of TBS, resuspended in $50 \mu \mathrm{l}$ of TBS per sample, and aliquoted into 1.5-ml tubes. Human plasma (2.5-40 $\mu \mathrm{l})$, TBS (blank), or rat plasma $(5-40 \mu \mathrm{l})$ were added and the total volume in each tube was increased to $500 \mu \mathrm{l}$ by adding TBS. The samples were incubated for $2 \mathrm{~h}$ at $25^{\circ} \mathrm{C}$ on a nutator, then spun for $30 \mathrm{~s}$ in a microfuge and washed six times with $1 \mathrm{ml}$ of TBS- $0.05 \%$ Tween 20 , once with $1 \mathrm{ml}$ of TBS, and resuspended in $300 \mu$ of TBS. $2 \mathrm{U}$ of Protac was added for $15 \mathrm{~min}$ at $25^{\circ} \mathrm{C}$, then chromogenic hPC substrate was added at a final concentration of $83 \mu \mathrm{M}$. After $12 \mathrm{~h}$ at $25^{\circ} \mathrm{C}$, the samples were spun in a microfuge for $1 \mathrm{~min}$ and the $\mathrm{OD}$ of the supernatant read at $405 \mathrm{~nm}$ in an ELISA reader. Blanks did not receive any plasma, and were subtracted from all samples. The activity observed using an equal volume of control rat (nontransduced) plasma was $1 \%$ of the activity observed with human plasma, and was subtracted from the calculated activity for each sample.

DNA analysis. DNA was isolated as described previously (45). To quantitate the copy number of the hPC-containing retroviral vector in the liver, a multiplex PCR technique involving primer sets that amplified both proviral (hPC) and rat genomic DNA (liver fatty acid binding protein promoter; LFABP) sequences was used. Primers hPC-502 (5'-GAGCTTCCTCAATTGCTCGCTGGAC-3'; top strand for nt 502-526) and hPC-1000 (5'-TGCGATGTCATTGTCGGTGGTGCTC-3'; bottom strand of nt 1000-976) amplified a 498-bp fragment. Primers LFABP-1 (5'-GCATTGCTAGAGATGTGATTCACATGTC-3'; top strand for nt 270-298) and LFABP-2 (5'-CCACAGCTGACCACAACAGCTCTG-3'; bottom strand for nt 623599) amplified a 353-bp fragment (50). Each 50- $\mu$ l PCR reaction included $50 \mathrm{ng}$ of DNA, $20 \mathrm{mM}$ Tris- $\mathrm{HCl}(\mathrm{pH} 8.55), 16 \mathrm{mM}\left(\mathrm{NH}_{4}\right)_{2} \mathrm{SO}_{4}$, $3.3 \mathrm{mM} \mathrm{MgCl}_{2}, 150 \mu \mathrm{g} / \mathrm{ml}$ bovine serum albumin, $2 \mathrm{mM}$ deoxynucleotide triphosphates, $25 \mathrm{pmol}$ of each oligonucleotide primer, and 1.25 U Thermus aquaticus DNA polymerase (Amplitaq; Perkin-Elmer, Norwalk, CT). 30 cycles were performed with denaturation at $94^{\circ} \mathrm{C}$ for $90 \mathrm{~s}$, annealing at $65^{\circ} \mathrm{C}$ for $90 \mathrm{~s}$, and extension at $72^{\circ} \mathrm{C}$ for $90 \mathrm{~s}$. Amplified DNA sequences were electrophoresed through a $\%$ agarose/1X Tris ammonium acetate gel, blotted to GeneScreen nitrocellulose membranes, and hybridized with a 1.4-kb hPC cDNA (39) probe labeled to a specific activity of $3 \times 10^{9} \mathrm{cpm} / \mu \mathrm{g}$ DNA with random primer labeling (49). After quantitation with a PhosphorImager, the membrane was stripped and rehybridized with a radiolabeled 620-bp LFABP (50) probe.
To quantitate the copy number of the IRES-containing retroviral vectors, PCR followed by Southern blot was performed using a primer set specific for the IRES and the LFABP primer set, as described previously (45).

RNase protection assay. RNA was isolated from rat liver using guanididium isothiocyanate as described previously (45). A plasmid containing the encephalomyocarditis IRES in pSP72 (Promega Corp., Madison, WI) was digested with HindIII to remove nt 236 to 570 of the IRES and religated to generate p746- $\Delta$ IRES. p746- $\Delta$ IRES was digested with BglII and transcribed with SP6 RNA polymerase, $\alpha-\left[{ }^{32} \mathrm{P}\right]$ UTP and unlabeled ATP, CTP, and GTP (49) to generate an antisense probe with a specific activity of $3 \times 10^{9} \mathrm{cpm} / \mu \mathrm{g} .40 \mu \mathrm{g}$ of RNA from rat liver or from a pool of NIH $3 \mathrm{~T} 3$ cells that were transduced with a single copy of hPC-701 was heated to $85^{\circ} \mathrm{C}$ for $10 \mathrm{~min}$ then hybridized for $5 \mathrm{~h}$ with $1 \times 10^{5} \mathrm{cpm}$ of radiolabeled probe in $30 \mu \mathrm{l}$ containing $80 \%$ formamide, $0.4 \mathrm{M} \mathrm{NaCl}, 1 \mathrm{mM}$ EDTA, and $40 \mathrm{mM}$ Pipes pH 6.4. Samples were digested at $37^{\circ} \mathrm{C}$ with $300 \mu$ of buffer containing $0.3 \mathrm{M} \mathrm{NaCl}, 10 \mathrm{mM}$ Tris- $\mathrm{HCl}, \mathrm{pH} 7.4$ and $5 \mathrm{mM}$ EDTA with $30 \mathrm{U} / \mathrm{ml}$ of RNase T1 (Calbiochem Corp., La Jolla, CA) and 1 $\mu \mathrm{g} / \mathrm{ml}$ of RNase A (Sigma Chemical Co.), extracted with phenol, and precipitated with ethanol. Samples were electrophoresed on an $8 \%$ polyacrylamide gel with $8 \mathrm{M}$ urea and $1 / 2 \times$ TBE $(45 \mathrm{mM}$ Tris base, $45 \mathrm{mM}$ boric acid, $1.25 \mathrm{mM}$ EDTA). The IRES-specific band was quantitated with a PhosphorImager.

\section{Results}

Production of a retroviral packaging cell line. The retroviral vectors designated as hPC-701 and hPC-702 are shown in Fig. 1. hPC-701 contains a modified hPC cDNA downstream of the ApoE enhancer-hAAT promoter, and the IRES-DHFR cassette that confers methotrexate resistance $\left(\mathrm{Mtx}^{\mathrm{R}}\right)$. The ApoEhAAT transcriptional elements were chosen because they directed high-level and long-term expression of the hAAT cDNA from a retroviral vector in rat liver in vivo (40). The sequence immediately upstream of the hPC translational initiation signal is GCCTCCAGA for the wild-type hPC cDNA. Since this sequence deviates from the consensus translational initiation signal described by Kozak (51), it was modified to contain the translational consensus sequence GCCGCCACC. hPC-702 is identical to hPC-701 except that it does not contain a selectable marker gene. The IRES-*DHFR was deleted to test the possibility that these sequences affected expression levels in vivo. The effect of the alteration in the $5^{\prime}$ untranslated

\section{hPC-701}
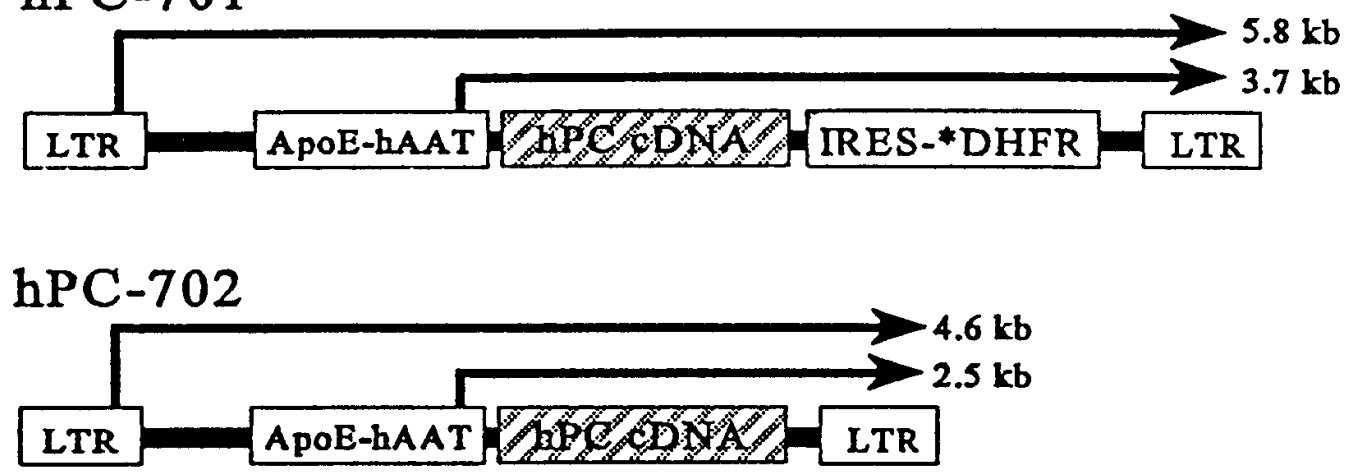

Figure 1. Retroviral vectors hPC-701 and hPC-702. hPC701 contains retroviral long terminal repeats $(L T R)$ at both ends, the apolipoprotein E (ApoE) enhancer:human $\alpha_{1}$-antitrypsin $(h A A T)$ promoter, the human protein $\mathrm{C}(h P C) \mathrm{cDNA}$, and the $1.2-\mathrm{kb}$ internal ribosome entry site (IRES)-mutant dihydrofolate reductase $\left({ }^{*} D H F R\right)$ cassette. The size of the mRNAs that initiate from the LTR or the hAAT promoter is indicated. hPC702 is similar except it does not contain the IRES*DHFR cassette. 
sequence upon the production of hPC protein was determined. A plasmid containing the wild-type hPC cDNA or the hPC cDNA with the altered $5^{\prime}$ untranslated sequence was placed downstream of the cytomegalovirus (CMV) immediate early promoter and was cotransfected into NIH 3T3 cells along with a separate plasmid expressing the human $\alpha_{1}$-antitrypsin (hAAT) cDNA. Both hPC constructs gave similar levels of expression after normalization for the hAAT protein in the supernatant, suggesting that the alteration of the $5^{\prime}$ untranslated sequence did not improve expression of hPC (data not shown).

These retroviral vector plasmids were used to create retroviral vector packaging cell lines, as described in the Methods section. The $\mathrm{Mtx}^{\mathrm{R}}$ titer of $\mathrm{hPC}-701$ was $2 \times 10^{5}$ colony forming units $(\mathrm{cfu}) / \mathrm{ml}$ on NIH $3 \mathrm{~T} 3$ cells. Southern blot of DNA from transduced NIH 3 T3 cells confirmed that hPC-701 had a titer of $\sim 2 \times 10^{5}$ infectious $\mathrm{U} / \mathrm{ml}$, and demonstrated that hPC-702 had a titer of $\sim 1 \times 10^{6}$ infectious $\mathrm{U} / \mathrm{ml}$ (data not shown). Pools of NIH $3 \mathrm{~T} 3$ cells that were transduced with one copy of hPC-701 per cell produced $251 \pm 42$ (SEM) ng of hPC/10 cells/ $24 \mathrm{~h}$. The hPC was $82 \pm 5.3 \%$ (SEM) functional, as determined by comparing the chromogenic substrate activity in serum-free conditioned medium from transduced NIH 3T3 cells with the antigen levels observed by immunoassay of the same samples. The amount of hPC produced by NIH 3T3 cells that were transduced with hPC-702 was consistently about fivefold higher than the amount of hPC produced by NIH 3T3 cells that were transduced with an equal volume of conditioned medium containing the hPC-701 vector. We conclude that the modified hPC cDNA used in this study results in the production of functional hPC. The hPC-702 retroviral vector confers higher expression of hPC upon transduced cells than hPC-701 in vitro, and this difference appears to be due primarily to its fivefold higher titer.

In vivo expression of $h P C$. hPC-701 and hPC-702 retroviral vectors were delivered to regenerating rat hepatocytes in vivo. Plasma obtained at various times after transduction was tested for hPC by immunoassay, as shown in Fig. 2, $A$ and $B$. For the first 2 wk after transduction, average expression of hPC in four hPC-701-transduced rats varied from $16-40 \mathrm{ng} / \mathrm{ml}$ (0.4-1.0\% of the level found in pooled normal human plasma), while expression in seven hPC-702-transduced rats was approximately fivefold higher at $55-203 \mathrm{ng} / \mathrm{ml}$ (1.3-5.0\% of normal). Expression fell to lower levels $(<50 \%$ of the average level observed during the first $2 \mathrm{wk}$ for that rat) thereafter in two of the hPC-701-transduced rats, and two of the hPC-702transduced rats. Two of the hPC-701-transduced rats exhibited stable expression (50-200\% of the initial levels for that rat) for $145 \mathrm{~d}$ after transduction, and one of the hPC-702-
A

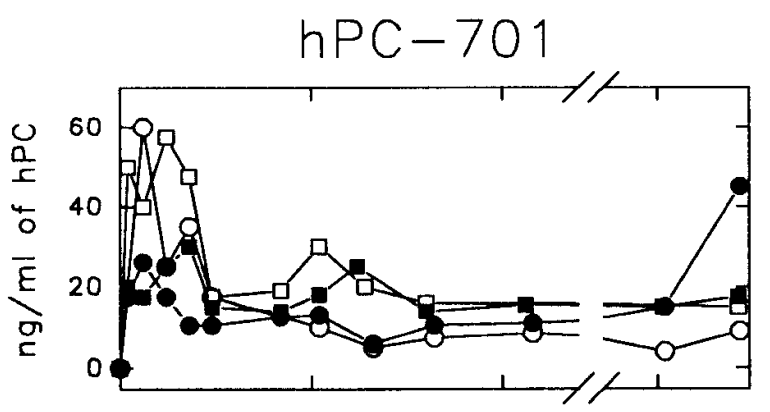

C

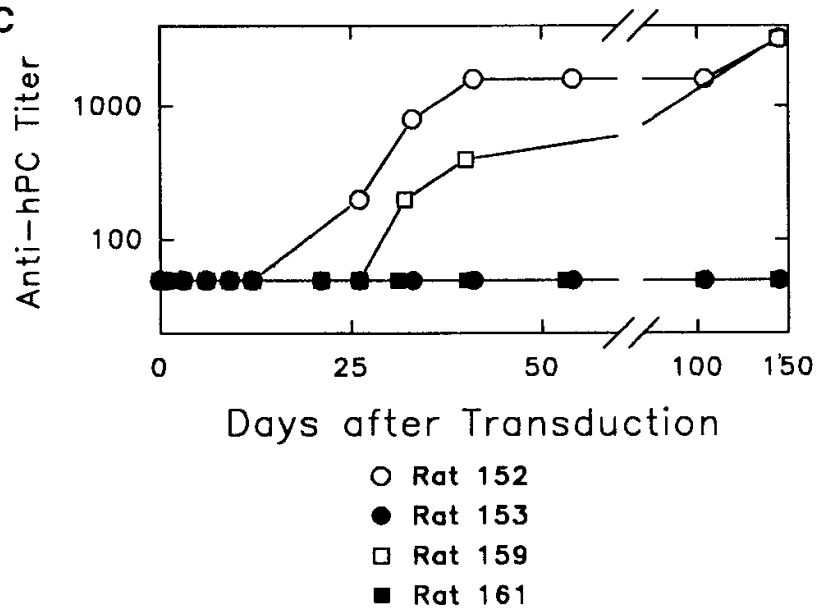

B

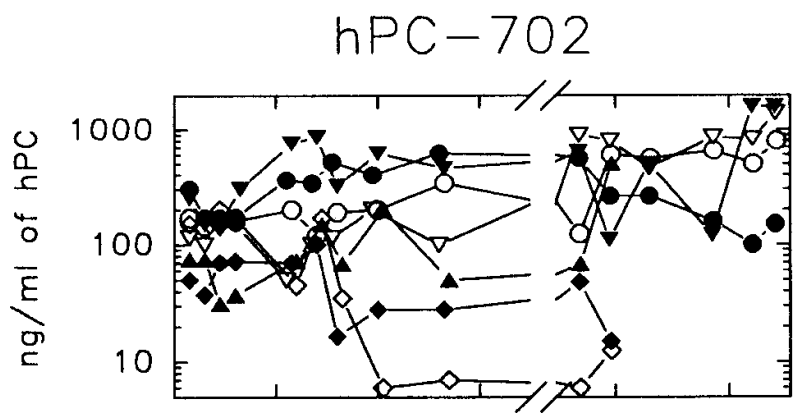

D

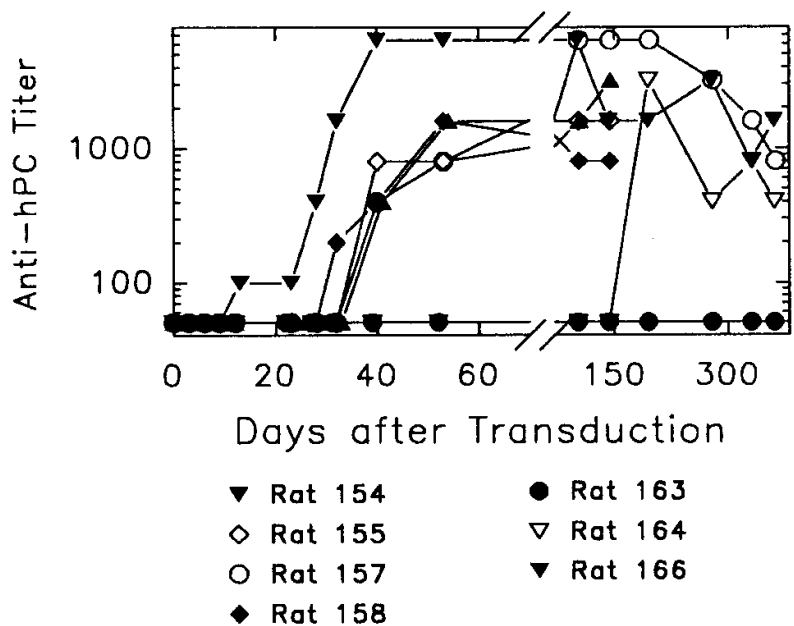

Figure 2. Expression of hPC-containing retroviral vectors in rats in vivo and quantitation of anti-hPC antibodies. Rats were treated with a $70 \%$ partial hepatectomy. $24 \mathrm{~h}$ later, $4 \mathrm{ml}$ containing ultracentrifuge-concentrated retroviral vector was injected into the portal vein. $(A) \mathrm{hPC}$ levels in hPC-701-transduced rats. Rats were transduced with $4 \times 10^{6} \mathrm{cfu}$ of hPC-701. Plasma was analyzed for hPC by ELISA. (B) hPC levels in hPC702-transduced rats. Rats were transduced with $2 \times 10^{7}$ infectious particles of hPC-702. (C) Anti-hPC antibody titer in hPC-701-transduced rats. Plasma was tested for anti-hPC antibodies at a 1:100 dilution as described in the Methods section. If the assay was negative, it was reported as having a titer of 1:50. If the assay was positive, it was serially diluted until a negative result was obtained, and the titer was reported as the highest dilution that was positive. $(D)$ Anti-hPC antibody titer in hPC-702-transduced rats. 
transduced rats exhibited stable expression for $361 \mathrm{~d}$. The four remaining hPC-702-transduced rats had a fourfold to ninefold increase in hPC levels at late time points as compared with the values obtained during the first 2 wk for that rat.

Anti-hPC antibody levels in retroviral vector-transduced rats. One possible explanation for the increase in hPC levels in some rats and the fall in others is that antibodies developed that led to increased or decreased clearance, respectively, of the human protein. We therefore tested rat plasma for the presence of anti-hPC antibodies. Both of the hPC-701-transduced rats that maintained stable levels of hPC for $145 \mathrm{~d}$ after transduction had no detectable anti-hPC antibodies for the duration of the experiment, as shown in Fig. 2 C. Rats 152 and 159, hPC-701-transduced rats whose hPC levels fell to 22 and $42 \%$, respectively, of their initial value, had anti-hPC antibodies that appeared at 1 mo after transduction and were present at a titer as high as 1:3,200. We conclude that two rats that had a fall in their hPC levels at 3 wk or later after transduction had anti-hPC antibodies, while two rats that exhibited stable expression did not.

hPC-702-transduced rats were also tested for the presence of anti-hPC antibodies in their plasma, as shown in Fig. 2 D. Rat 163, who exhibited stable expression of hPC for $1 \mathrm{yr}$ after transduction, did not develop anti-hPC antibodies. Rats 155 and 158, hPC-702-transduced rats whose hPC levels fell to 26 and $4 \%$ of their initial values, developed anti-hPC antibodies with a peak titer of 1:1,600 and 1:800, respectively. Rats 154, 157,164 , and 166, which exhibited a fourfold to ninefold increase in hPC levels at $3 \mathrm{wk}$ or later after transduction, had anti-hPC antibodies with a peak titer of 1:3,200 to 1:6,400. We conclude that anti-hPC antibodies were present in hPC-702-

\section{3 hrs $6.7 \mathrm{hrs} 2.7 \mathrm{hrs} 6 \mathrm{hrs}$ Half-life $<1: 100 \quad 1: 6400<1: 100$ 1:6400 Antibody $\overbrace{123621}^{\text {Cont }} \overbrace{\overbrace{23621}^{157}}^{163} \overbrace{123621}^{164} \overbrace{123621}^{\text {Rat }}$ Hours $-\mathrm{hPC}$}

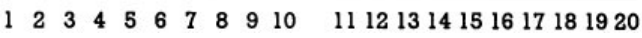

Figure 3. hPC half-life in rats. hPC-702-transduced rats were injected with $6 \times 10^{7} \mathrm{cpm}$ of $\left[{ }^{125} \mathrm{I}\right]-\mathrm{hPC}$ at $360 \mathrm{~d}$ after transduction and plasma was obtained from a different site at $1-24 \mathrm{~h}$ later. $0.5 \mu \mathrm{l}$ of plasma was electrophoresed on nonreducing SDS-PAGE, and an autoradiogram was obtained. The number above each lane represents the hours after injection of label that the plasma sample was collected. Lanes 1-5 (Cont) represent a Lewis rat of similar weight that was never injected with any retroviral vector. Lanes 6-10 (Rat 157) and lanes 16-20 (Rat 164) represent rats that received the hPC-702 retroviral vector, developed anti-hPC antibodies, and exhibited an increase in hPC levels over time. Lanes 11-15 (Rat 163) represent a rat that received the hPC-702 retroviral vector, but did not develop anti-hPC antibodies or exhibit an increase in hPC levels over time. The peak anti-hPC antibody titer is indicated for each rat. The calculated hPC half-life in hours, which was based upon PhosphorImaging of the gel, is also shown. transduced rats that exhibited an increase in hPC levels over time as well as in rats that had a fall in hPC protein levels.

$h P C$ half-life in retroviral vector-transduced rats. It is possible that rats that developed anti-hPC antibodies and an increase in their hPC plasma levels over time had an increase in the hPC half-life in their blood. To measure the half-life of the protein, radiolabeled hPC was injected into the penile vein, and plasma samples were obtained from the eye at various times thereafter. Plasma samples were electrophoresed on nonreducing SDS-PAGE and the amount of hPC was quantitated by PhosphorImaging. Controls consisted of one rat that was never transduced with any retroviral vector, and two rats that were transduced with a retroviral vector that directs expression of another protein, hAAT. The amount of hPC present at the initial timepoint of $1 \mathrm{~h}$ was 1.5 - to 2.8 -fold higher in rats that had high-titer anti-hPC antibodies and an increase in the hPC levels over time (Fig. 3, lanes 6 and 16), than in a control rat (Fig. 3, lane 1) or a transduced rat that did not have anti-hPC antibodies (Fig. 3, lane 11). This suggests that the initial clearance of hPC was slower in rats with anti-hPC antibodies than in rats without anti-hPC antibodies.

The plasma half-life was determined by quantitating the amount of hPC present at $1 \mathrm{~h}$ or later after transduction and is listed in Table I. The three control rats had an average hPC half-life of $2.6 \pm 0.2 \mathrm{~h}$. This was similar to the half-life of nonlabeled hPC in four different control rats, in which the hPC levels in plasma were quantitiated by ELISA (data not shown). Rats 157, 164, and 166 (transduced with hPC-702; developed high-titer anti-hPC antibodies and an increase in hPC levels over time) all had half-lives that were two- to threefold higher than controls. Rat 163, which was transduced with hPC-702 but did not develop antibodies, had a half-life of $2.75 \mathrm{~h}$, which did not differ from the controls. We conclude that the antihPC antibodies probably decrease the rate of clearance of hPC in the plasma of some rats, and may be responsible for the increase in hPC levels that was observed in these animals.

There were four rats that had a decline in hPC levels concurrent with the development of anti-hPC antibodies. We believe that the hPC half-life would have been shorter in these animals than in controls. Unfortunately, however, these rats were killed before the half-life study was performed so it is impossible to confirm this hypothesis.

hPC functional activity in rat plasma. The above studies led us to conclude that the hPC antigenic levels might be increased in some rats because of antibodies that lead to decreased clearance. It is possible that such an antibody might inhibit the functional activity of the hPC protein. Functional assays for protein $\mathrm{C}$ activity are complicated by the presence of rat protein $\mathrm{C}$ in normal rat plasma. To overcome this difficulty, rat plasma was immunoprecipitated with a human specific anti-hPC antibody, the hPC was activated with Protac, and a chromogenic substrate specific for protein $\mathrm{C}$ was added. The results of this assay are shown in Table I. The functional activity in the immunoprecipitation/chromogenic substrate assay correlated reasonably well with the levels of antigen that were detected by ELISA for most rats. Discrepancies could be due to interference from the rat antibodies in either assay, or to the inaccuracies of the multistep immunoprecipitation/chromogenic substrate assay. We conclude that the hPC was functional despite the presence of hPC antibodies, as it could be activated by Protac and could cleave a small chromogenic substrate. 
Quantitation of DNA copy number in rat livers in vivo. It is important to determine the DNA copy number of the retroviral vectors in the liver for two reasons. First, the expression levels in vivo will be a reflection of the expression per copy and the number of copies delivered. Second, some animals exhibited an increase in their hPC levels over time. One explanation for these increased levels is that ongoing retroviral vector replication occurred that increased the DNA copy number in the liver, resulting in increased expression.

The retroviral vector copy number in the livers of hPCtransduced rats was determined by using a multiplex PCR reaction following by Southern blot, as shown in Fig. 4. Primers specific for the hPC gene were used to identify the retroviral vector sequences in either hPC-701- or hPC-702-transduced rats, and primers specific for rat genomic DNA (LFABP) were used as a control for the efficiency of PCR amplification. A

\section{Table I. Summary of Results in Rats}

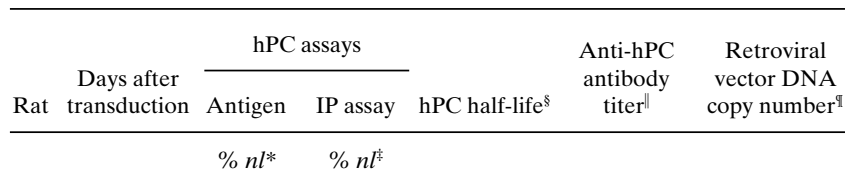

Controls

$$
0 \quad 0 \quad 2.6 \pm 0.2 \mathrm{~h}<1: 100 \quad 0
$$

hPC-701-transduced rats

$\begin{array}{ccccccc}152 & 145 & 0.2 & 0 & \text { NT } & 1: 3200 & 1.0 \pm 0.7 \% \\ 153 & 145 & 1.1 & 0 & \text { NT } & <1: 100 & 3.2 \pm 2 \% \\ 159 & 144 & 0.4 & 0 & \text { NT } & 1: 3200 & 0.2 \pm 0.1 \% \\ 161 & 145 & 0.4 & 0 & \text { NT } & <1: 100 & \text { NT }\end{array}$

hPC-702-transduced rats

$\begin{array}{ccccccc}154 & 145 & 12.5 & 35 \pm 4 & \mathrm{NT} & 1: 3200 & 11.3 \pm 5 \% \\ 155 & 145 & 0.4 & 0 & \mathrm{NT} & 1: 1600 & \mathrm{NT} \\ 157 & 332 & 12.5 & 21.9 \pm 0.1 & \mathrm{NT} & 1: 1600 & \mathrm{NT} \\ & 362 & 20 & 20.6 \pm 3 & 6.7 \pm 2.6 \mathrm{~h} & 1: 1600 & 15.8 \pm 4 \% \\ 158 & 145 & 0.3 & 1 \pm 0.3 & \mathrm{NT} & 1: 800 & \mathrm{NT} \\ 163 & 331 & 2.5 & 5.0 \pm 1 & \mathrm{NT} & <1: 100 & \mathrm{NT} \\ & 361 & 3.75 & 1.8 \pm 0.7 & 2.7 \pm 1.1 \mathrm{~h} & <1: 100 & 32.5 \pm 10 \% \\ 164 & 9 & 0.3 & 3 \pm 0.5 & \mathrm{NT} & <1: 100 & \mathrm{NT} \\ & 330 & 47 & 182 \pm 13 & \mathrm{NT} & 1: 400 & \mathrm{NT} \\ & 360 & 35 & 60.1 \pm 2 & 6.0 \pm 2.3 \mathrm{~h} & 1: 400 & 8.8 \pm 3 \% \\ 166 & 9 & 4 & 4.1 \pm 0.3 & \mathrm{NT} & <1: 100 & \mathrm{NT} \\ & 330 & 75 & 87.5 \pm 4 & \mathrm{NT} & 1: 1600 & \mathrm{NT} \\ & 360 & 40 & 49.6 \pm 2 & 7.5 \pm 2.9 \mathrm{~h} & 1: 1600 & 20.8 \pm 5 \%\end{array}$

Plasma was obtained at various times after transduction with hPC-701 or hPC-702. Controls consisted of nontransduced rats and rats that were transduced with a retroviral vector that expressed hAAT. For all transduced rats, the rat number and the time after transduction that the sample was analyzed are shown. ${ }^{*}$ The hPC antigenic activity as a percentage of normal is shown. ${ }^{*}$ The hPC functional activity was determined using the immunoprecipitation/chromogenic substrate $(I P)$ assay, and is reported as the percentage of normal human activity. ${ }^{\S}$ The hPC half-life in hours was determined after injection of radiolabeled hPC, as shown in Fig. 3. "The anti-hPC IgG antibody titer was determined as shown in Fig. 2, $C$ and $D$. "The transduction efficiency was determined by using the PCR-based assay shown in Fig. 4. The percentage of liver cells that were transduced is shown. This was determined by performing the PCR-based assay for DNA copy number three times and averaging the results. For all columns, the result \pm the standard deviation is shown. NT, not tested.

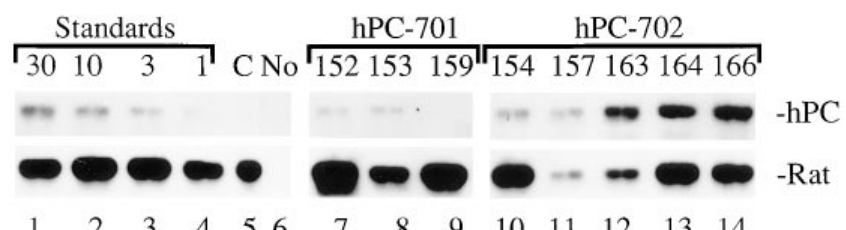

Figure 4. DNA analysis of retroviral vector-transduced rat livers. Rat livers were obtained at the time of death, and DNA was isolated. PCR was performed using primers specific for the hPC gene of the retroviral vector and rat genomic DNA. Southern blot was performed using an hPC probe $(h P C)$ followed by stripping and hybridization with an LFABP probe (Rat). Standards (lanes 1-4) contain DNA from NIH 3T3 cells with one copy of hPC-701 per cell diluted with DNA from a nontransduced rat liver. The number above each lane represents the percentage of DNA that was derived from the singly transduced NIH 3 T3 cells. Lane $5(C)$ shows DNA from a nontransduced rat, while lane $6(\mathrm{No})$ shows a sample that had no DNA added. Lanes 7-9 show DNA from hPC-701-transduced rats, while lanes 10-14 show DNA from hPC-702-transduced rats. The animal number is listed above each lane.

sample without any DNA added (Fig. 4, lane 6) had no signal with either probe, as expected. Rat liver DNA (Fig. 4, lane 5) that was isolated in parallel with the experimental rat samples had a signal for LFABP but no signal for hPC, demonstrating that the primers are specific for the human protein $\mathrm{C}$ gene and that contamination of the rat DNA samples with hPC-containing sequences had not occurred. The standards shown in Fig. 4, lanes 1-4 were used to estimate the retroviral vector transduction efficiency for transduced rats.

The percentage of hepatocytes from hPC-701-transduced rats that contained the retroviral vector varied from 1 to $4 \%$, with an average of $1.5 \%$. The retroviral vector DNA copy number in hPC-702-transduced rats varied from 9 to $33 \%$, with an average of $18 \%$. This difference in transduction efficiency is consistent with the fact that the titer of hPC-702 was fivefold higher than that of hPC-701. Discrepancies in the ratio of the titer to the in vivo transduction efficiency are likely due to inherent inaccuracies in determination of titer by Southern blot and determination of the in vivo transduction efficiency by the PCR-based method. Previous studies demonstrated a direct relationship between the number of retroviral vector particles injected and the transduction efficiency $(45,52)$. These data demonstrate that the higher expression of hPC observed in the hPC-702-transduced rats as compared with the hPC-701-transduced rats was primarily due to the fact that more copies of the hPC-702 retroviral vector were delivered. The DNA copy number in hPC-702-transduced rats that exhibited an increase in hPC protein in the blood at late timepoints (rats 157, 164, and 166) was similar to the DNA copy number in a rat that did not have this increase (rat 163). We conclude that it is unlikely that the increase in hPC levels in these rats was due to an increase in the retroviral vector copy number in the liver because of ongoing infection.

Analysis of DNA and RNA from rats transduced with similar retroviral vectors containing different $c D N A s$. The level of expression of $\mathrm{hPC}$ in the hPC-701-transduced rats $(27 \pm 4.7$ [SEM] ng/ml, or $0.44 \mathrm{nM}$ ) was lower than what we had observed previously after delivery of similar high-titer retroviral vectors containing other cDNAs, as summarized in Table II. 
Table II. Comparison of Protein Levels, DNA Copy Number, and RNA Levels in Rats That Were Transduced with Retroviral Vectors with the Human $\alpha_{1}$-antitrypsin Promoter and the IRES-*DHFR Cassette but Expressed Different $c D N A s$

\begin{tabular}{lccc}
\hline Retroviral vector & $\begin{array}{c}\text { Protein level } \\
\text { in blood* }\end{array}$ & $\begin{array}{c}\text { DNA copy } \\
\text { number }\end{array}$ & RNA levels \\
\hline & & $\%$ transduction & \\
hFX-514 & $1747 \pm 387 \mathrm{ng} / \mathrm{ml}$ & $1.6 \pm 0.6$ & $585 \pm 102 \%$ \\
hAAT-540B & $475 \pm 141 \mathrm{ng} / \mathrm{ml}$ & $0.5 \pm 0.1$ & $252 \pm 67 \%$ \\
hPC-701 & $27 \pm 4.7 \mathrm{ng} / \mathrm{ml}$ & $1.6 \pm 0.7$ & Weakly positive
\end{tabular}

* Protein levels in blood were determined by testing serum (hAAT) or plasma (hFX and hPC) for the appropriate antigen level using a humanspecific ELISA. "DNA copy number was determined by multiplex PCR using primers specific for the retrovirus (IRES) and rat genomic DNA (LFABP), as shown in Fig. $5 \mathrm{~A} .{ }^{\S}$ RNA levels were determined by using an RNase protection assay with a probe specific for the IRES, as shown in Fig. 5, $B$ and $C$. The level of RNA relative to a pool of NIH 3T3 cells that were transduced with a single copy of hPC-701 is shown. RNA levels from the hPC-701-transduced rats were difficult to quantitate as the signal was just barely above the background level. Averages \pm SEM are shown.

$\mathrm{hFX}-514$ is a retroviral vector that is identical to hPC-701 except it contains the hFX cDNA instead of the hAAT cDNA, and does not contain the ApoE enhancer. hAAT-540B is a retroviral vector that is identical to hPC-701 except it contains the hAAT cDNA instead of the hPC cDNA. The hFX level in hFX-514-transduced rats was 1,747 $387 \mathrm{ng} / \mathrm{ml}$, or $28 \mathrm{nM}$ (36). The hAAT level in our initial report in hAAT-540B-transduced rats was $5,385 \pm 2,408 \mathrm{ng} / \mathrm{ml}$, or $108 \mathrm{nM}(40)$. However, the hAAT-540B-transduced rats whose DNA and RNA are analyzed here received 10-fold fewer retroviral particles and the average hAAT level was correspondingly lower at $475 \pm$ $141 \mathrm{ng} / \mathrm{ml}(36)$.

Possible explanations for decreased expression of hPC in this study as compared with expression of other cDNAs in previous studies include delivery of fewer retroviral vector particles, decreased levels of transcription, decreased mRNA stability, decreased protein translation or secretion, or decreased half-life of the protein in blood. To try to identify which of these mechanisms might contribute to the lower levels of hPC obtained in vivo, we quantitated the retroviral vector DNA and RNA levels in livers from rats that were transduced with each of these retroviral vectors. These assays used probes specific for the IRES sequences that are present on all three vectors.

Quantitation of the DNA copy number in rats that were transduced with different retroviral vectors is shown in Fig. 5 $A$ and summarized in Table II. In this assay, the hFX-514transduced rats had an average retroviral vector DNA copy number of $1.6 \pm 0.6 \%$ (SEM), the hAAT-transduced rats had an average DNA copy number of $0.5 \pm 0.1 \%$, and the hPC-701-transduced rats had an average copy number of $1.6 \pm 0.7 \%$, as summarized in Table II. These data are consistent with the DNA copy number determined previously for hFX-514- and hAAT-540B-transduced rats using the IRES primers, and for the hPC-701-transduced rats using the hPC- specific PCR-based assay. We conclude that differences in transduction efficiency are minor and cannot account for the $>20$-fold lower expression that was observed with hPC-701transduced rats as compared with rats that were transduced with hFX or hAAT.

RNA levels were determined using an RNase protection assay specific for the IRES sequences that are present on all three retroviral vectors, as shown in Fig. 5, $B$ and $C$. RNA obtained from the hFX-514-transduced rats (Fig. 5, lanes 2-5) gave a signal that was sixfold stronger than the signal from hPC-701-transduced NIH 3 T3 cells. hAAT-540B-transduced rats (Fig. 5, lanes 6 and 7) had a signal that was $43 \%$ of that observed in hFX-514-transduced rats. The signal from hPC-701transduced rats (Fig. 5, lanes 8-10) was only slightly higher than the signal observed in the control (nontransduced) rat shown in Fig. 5, lane 1, and could not be accurately quantitated. The RNase protection assay was also performed using other digestion conditions, and we consistently obtained a much fainter signal with RNA from hPC-701-transduced rats than with RNA from rats transduced with the other retroviral vectors (not shown). We conclude that hPC-701-transduced rats have less retroviral vector RNA in their liver than rats that were transduced with retroviral vectors containing other cDNAs, although the DNA copy number was similar or higher for the hPC-701-transduced rats as compared with the other rats. This suggests that the hPC coding sequences affect either transcription or mRNA stability.

\section{Discussion}

Severe homozygous hPC deficiency is a serious disorder that results in spontaneous thrombosis and DIC if untreated. Although treatment with frequent parenteral infusions of purified $\mathrm{hPC}$ is effective in preventing these clinical manifestations, the high cost and the need for close medical supervision will likely limit this approach in humans once hPC concentrates are approved for clinical use. The alternative treatment, life-long anticoagulation with coumadin, is complicated by bleeding or thrombosis during periods of over- or anticoagulation, respectively. Thus, successful gene therapy for severe hPC deficiency would dramatically improve the quality of life of patients with this disorder.

Therapeutic levels of expression of $h P C$ were achieved in some rats. In this study, two different retroviral vectors were delivered to the liver in vivo during hepatocyte regeneration. During the first $2 \mathrm{wk}$ after transduction, hPC-701-transduced rats had an average hPC level of $27.5 \pm 4.7$ (SEM) ng/ml $(0.7 \%$ of normal human levels), while hPC-702-transduced rats had an average $\mathrm{hPC}$ level of $134.1 \pm 22.1 \mathrm{ng} / \mathrm{ml}$ (3.3\% of normal). The higher expression in the hPC-702-transduced rats was probably due to the fact that the transduction efficiency $(18 \%$ of hepatocytes) was higher than that of the hPC-701-transduced rats $(1.5 \%)$. We consider the level of expression that was achieved during these 2 wk to be indicative of what would have been maintained long-term in the absence of anti-hPC antibody formation.

The hPC was functional as determined by using a chromogenic substrate assay after immunoprecipitation with human-specific hPC antibodies and activation with Protac. We also activated the protein $\mathrm{C}$ present in rat plasma with Protac, and tested its anticoagulation activity in an APTT assay with hPC-deficient human plasma. Addition of $5 \mu \mathrm{l}$ of plasma from 

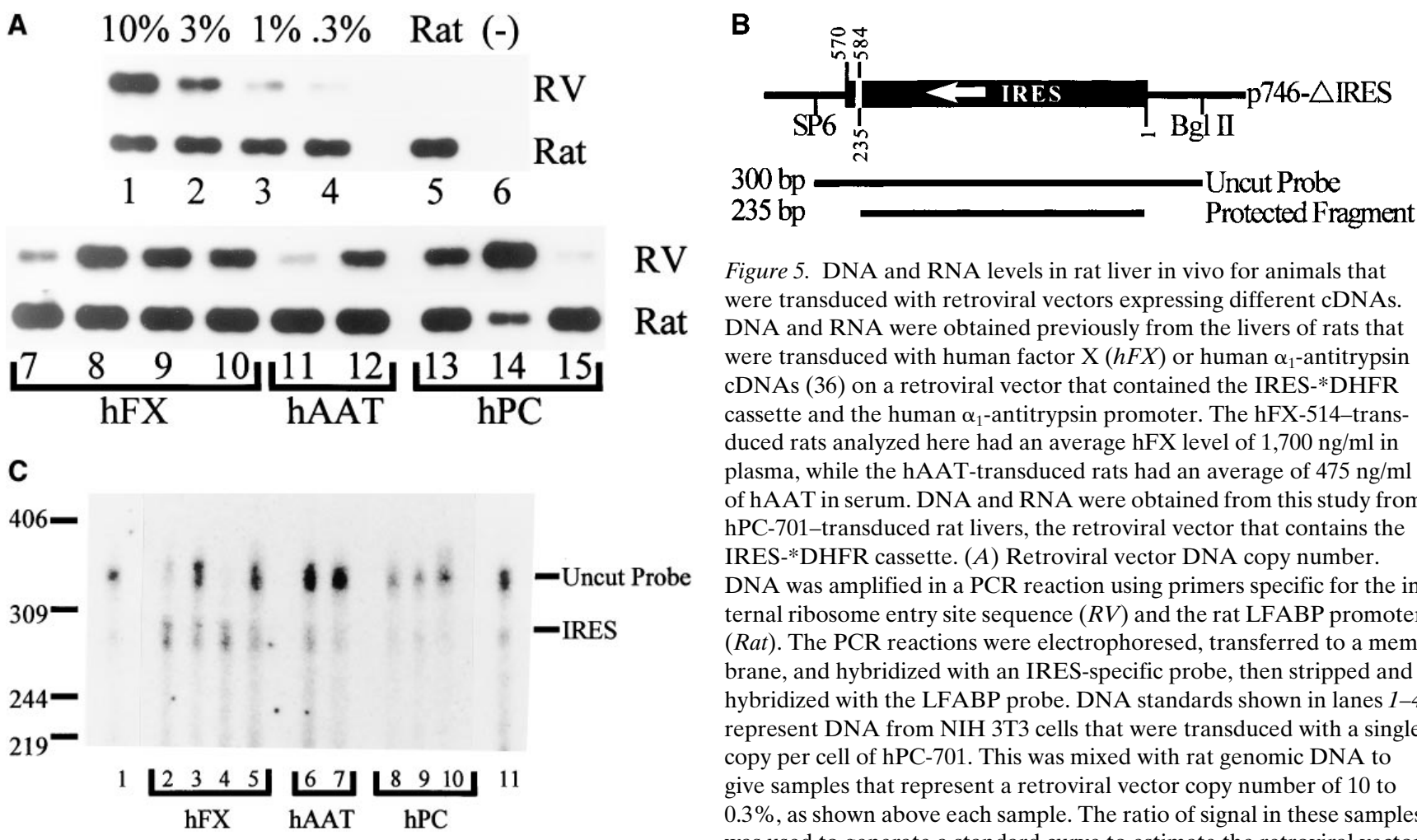

Figure 5. DNA and RNA levels in rat liver in vivo for animals that were transduced with retroviral vectors expressing different cDNAs. DNA and RNA were obtained previously from the livers of rats that were transduced with human factor $\mathrm{X}(h F X)$ or human $\alpha_{1}$-antitrypsin cDNAs (36) on a retroviral vector that contained the IRES-*DHFR cassette and the human $\alpha_{1}$-antitrypsin promoter. The hFX-514-transduced rats analyzed here had an average $\mathrm{hFX}$ level of $1,700 \mathrm{ng} / \mathrm{ml}$ in plasma, while the hAAT-transduced rats had an average of $475 \mathrm{ng} / \mathrm{ml}$ of hAAT in serum. DNA and RNA were obtained from this study from hPC-701-transduced rat livers, the retroviral vector that contains the IRES-*DHFR cassette. ( $A$ ) Retroviral vector DNA copy number.

DNA was amplified in a PCR reaction using primers specific for the internal ribosome entry site sequence $(R V)$ and the rat LFABP promoter $(R a t)$. The PCR reactions were electrophoresed, transferred to a membrane, and hybridized with an IRES-specific probe, then stripped and hybridized with the LFABP probe. DNA standards shown in lanes 1-4 represent DNA from NIH 3 T3 cells that were transduced with a single copy per cell of hPC-701. This was mixed with rat genomic DNA to give samples that represent a retroviral vector copy number of 10 to $0.3 \%$, as shown above each sample. The ratio of signal in these samples was used to generate a standard curve to estimate the retroviral vector DNA copy number for the rat liver samples. DNA from a control nontransduced animal (Rat) is shown in lane 5, while lane 6 ( - ) did not have any DNA added. The samples shown in lanes 7-10 represent DNA obtained from hFX-514-transduced rats, lanes 11 and 12 represent DNA from hAAT-540B-transduced rats, and lanes 13-15 represent hPC-701-transduced rats. (B) Antisense RNA used in an RNase protection assay to determine the amount of retroviral vector RNA. A portion of p746- $\triangle$ IRES, a plasmid that contains the IRES, is shown. This contains IRES sequences from nucleotide 1 to 235, and 570 to 585. After linearization with BglII, transcription with SP6 RNA polymerase results in a 300-bp RNA probe which is complementary to the IRES present in all three retroviral vectors. When this probe is hybridized with IRES-containing retroviral RNA and digested with single-strand specific, a 235-nt band is protected. $(C)$ RNase protection assay using rat liver RNA and the antisense IRES probe. RNA was hybridized with the antisense IRES probe shown in panel $B$, digested with single-stranded RNA-specific RNases, and electrophoresed on a denaturing polyacrylamide gel. The position and size of end-labeled pBR322 MspI DNA markers is shown on the left. The position of the uncut 300-nt probe (Uncut probe) and the 235-nt band that is protected from digestion in the presence of IRES-containing RNA (IRES) are shown on the right. Note that RNA migrates $\sim 10 \%$ slower than DNA with the same number of nucleotides because of the extra hydroxyl group. Lane 1 shows RNA from a control (nontransduced rat). Lanes 2-5 represent RNA from hFX-514-transduced rats, lanes 6 and 7 represent RNA from hAAT-540B-transduced rats, and lanes 8-10 represent RNA from hPC-701-transduced rats. Lane 11 contains RNA from hPC-701-transduced NIH 3T3 cells.

all of the animals with high hPC levels to $75 \mu$ l of hPC-deficient plasma resulted in a prolongation of the APTT, as compared with the APTT observed using an equal amount of plasma from a variety of normal rat controls (data not shown). Although this suggests that the hPC was functionally active at inhibiting coagulation, quantitative of the hPC levels was complicated by the fact that addition of rat plasma to hPC-deficient human plasma markedly blunted the prolongation of the APTT that is otherwise observed when Protac-activated hPC is added to hPC-deficient human plasma. hPC activity is rapidly inhibited by rat plasma (53; data not shown), which is likely due to interaction of hPC with known inhibitors of protein $\mathrm{C}$ such as protein $\mathrm{C}$ inhibitor or $\alpha_{1}$-antitrypsin (54-56). In addition, species differences in the interaction of $\mathrm{PC}$ with its cofactor protein S and its substrates factor Va and VIIIa (53) may also complicate determination of hPC activity in a coagulation-based assay. Thus, although the prolongation of the APTT with Protac-activated plasma from transduced rats with high hPC antigen levels suggests that the hPC functioned to inhibit coagulation, the problems of this heterologous system precluded precise quantitatation of the amount of functional hPC present. We therefore consider the antigen levels achieved to be most predictive of whether or not a therapeutic effect would be observed in humans.

Homozygous hPC-deficient patients with 5-20\% of normal hPC levels usually do not experience purpura fulminans or DIC, although they may present with thrombosis as young adults (57-60). Similarly, purpura fulminans and DIC can be prevented in patients with severe hPC deficiency by achieving $>10 \%$ of normal human levels by injection of hPC concentrates (11). Thus, a minimal therapeutic goal would be to achieve $5-10 \%$ of normal hPC levels, although it would be preferable to achieve $100 \%$ of normal human levels. Most of the hPC-702-transduced rats achieved a level of expression that would have a significant effect upon the clinical manifestations of severe hPC deficiency. We plan to determine if the hPC-expressing retroviral vectors will prevent the spontaneous thrombosis and early death that occurs in homozygous mice 
whose protein $\mathrm{C}$ gene has been knocked out by homologous recombination (61).

The level of hPC achieved in rats was 20-fold lower than the levels of two other plasma proteins, hAAT and hFX, that were expressed from a similar retroviral vector using similar delivery methods, as summarized in Table II. The production of hPC protein in hPC-701-transduced NIH $3 \mathrm{T3}$ (fibroblast) cells in vitro in this study was similar to the in vitro expression of hFX or hAAT by hFX-514- (36) or hAAT-540B-transduced (40) cells, respectively, in previous studies, suggesting that differences in expression only occurred in the liver in vivo. It is unlikely that differences in protein half-life can account for the discrepancy in protein expression. Although the half-life of hAAT is considerably longer in mice at $\sim 24 \mathrm{~h}(62)$ than the half-life of hPC in rats $(2.6 \mathrm{~h})$, the half-life of hFX in blood at $3.5 \mathrm{~h}$ in rats (Le, M., and K. Ponder, unpublished data) is similar to that of hPC in normal rats. Differences in transduction efficiency cannot account for the discrepancy in protein expression, as the DNA copy number in the liver in vivo was similar for the different retroviral vectors.

The levels of retroviral vector-derived transcripts were lower for the hPC-701-transduced rats than they were for the hFX-514- or hAAT-540B-transduced rats, as determined by using an RNase protection assay. This suggests that the presence of the hPC cDNA resulted in decreased transcription or decreased mRNA stability. Attempts to quantitate the transcription rate of the various constructs in the liver using a runon transcription assay have not been successful to date but are being continued. These data demonstrate that expression of different genes from a retroviral vector may vary considerably in vivo, and that gene sequences may alter the transcription and/or half-life of an mRNA in vivo.

Antibodies probably prolonged the hPC half-life and increased the $h P C$ levels in some rats. The immunological response to a foreign protein will be an important consideration for gene therapy in human patients, which usually lack some or all of the epitopes of a protein. In this study, four rats developed anti-hPC antibodies and exhibited a four- to ninefold increase in the hPC levels. Three of these four rats were studied to determine the hPC half-life, and all had a two- to threefold longer half-life than a variety of controls that did not have antihPC antibodies. Despite these antibodies, the hPC was biologically active in an immunoprecipitation/chromogenic substrate assay. We believe that the anti-hPC antibodies resulted in the prolonged hPC half-life. Alternative explanations, such as the possibility that animals with a longer hPC half-life are more likely to develop antibodies, appear to be unlikely in these inbred rats, but cannot be excluded by this study. Three other rats had no significant antibodies and stable expression of $\mathrm{hPC}$, while four rats had anti-hPC antibodies and hPC plasma levels that fell to $4,22,26$, or $42 \%$ of their initial levels. Although we hypothesize that the latter rats would have exhibited a decrease in the hPC half-life commensurate with the decrease in hPC levels, these animals were killed before the hPC half-life study was performed.

Some investigators working in the field of gene therapy have assumed that the production of antibodies will necessarily result in increased clearance and decreased levels of a plasma protein in animals $(63,64)$. In this study, although three rats had a moderate decline and one had a severe decline in hPC levels coincidentally with the development of anti-hPC antibodies, four rats had an increase in functionally active hPC levels and a prolongation of the hPC half-life that was presumably due to antibodies. We conclude that the development of antibodies does not necessarily lead to increased clearance or inactivation of the biological effect of the protein. Our data are consistent with the fact that a large fraction of patients that are treated with porcine insulin (65-68), growth hormone (69), factor VIII (70), or glucocerebrosidase $(71,72)$ develop antibodies, and the majority of these antibodies do not have an adverse effect upon the biological response to the protein. Indeed, most patients that were treated with porcine insulin developed antibodies that prolonged the half-life of radiolabeled insulin in vivo without blocking its effects upon glucose metabolism (65-68). Although antibodies that block the effect of a protein can pose a serious clinical problem for the treatment of diabetes, growth hormone deficiency, hemophilia, or Gaucher disease $(65-70 ; 73)$, we conclude that not all antibodies are deleterious. It is likely that the immunological response to a protein that is delivered by gene therapy procedures will not differ significantly from that of infused protein, although it will be necessary to assess the immunological response to proteins after gene therapy procedures are performed in humans. In a series of nine patients who received intermittent or continuous injection of hPC concentrates, none have developed antibodies to date (11).

Implications for human gene therapy. Retroviral-mediated hepatic gene therapy has been limited in humans because of subtherapeutic protein expression and the surgical risks associated with the genetic modification of hepatocytes. The first problem, that of low-level expression, can be overcome by using a strong liver-specific promoter and delivering a large number of retroviral vector particles in vivo, as was done in this study.

The second major obstacle is that in vivo and ex vivo approaches (24) require a major surgical procedure such as the $70 \%$ partial hepatectomy that was performed in this study to induce hepatocyte replication. We have used $70 \%$ portal branch occlusion to induce apoptosis of the occluded liver and compensatory replication of the nonoccluded liver in rats (74) and pigs (75) with little morbidity. Alternatively, efficient in vivo retroviral vector transduction was achieved in mice after hepatocyte replication was induced by the administration of keratinocyte growth factor (76) or hepatocyte growth factor (77). There are therefore a variety of less toxic avenues for facilitating in vivo retroviral vector delivery to the liver that are currently being explored. The inefficiency of retroviral vectormediated gene transfer in large animals (34) is likely due to the failure to deliver a sufficient number of retroviral vector particles to the liver during the peak period of hepatocyte replication. Improvements in production of higher-titer retroviral vector particles and identification of the time period during which hepatocyte replication occurs should make it possible to improve the transduction efficiency in large animals. If these approaches are successful and safe, in vivo retroviral vectormediated gene therapy will be a very attractive method for permanently correcting the clinical manifestations of patients with severe hPC deficiency.

\section{Acknowledgments}

We thank Dr. J. Miletich for purified hPC and for assistance with $\mathrm{hPC}$ assays, and Dr. E. Davie for the hPC cDNA.

This work was supported by research grant No. 1-FY96-0176 
from the March of Dimes Birth Defects Foundation and DK48028 from the National Institutes of Health awarded to K.P. Ponder.

\section{References}

1. Reiner, A.P., and E.W. Davie. 1995. Introduction to hemostasis and the vitamin K-dependent coagulation factors. In The Metabolic and Molecular Bases of Inherited Disease. 7th ed. Scriver, C.R., A.L. Beaudet, W.S. Sly, and D. Valle, editors. McGraw Hill Inc., New York. 3181-3221.

2. Reitsma, P.H., F. Bernardi, R.G. Doig, S. Gandrille, J.S. Greengard, H Ireland, M. Krawczak, B. Lind, G.L. Long, S.R. Poort, et al. 1995. Protein C deficiency: a database of mutations, 1995 update. Thromb. Haemostasis. 73:876889.

3. Miletich, J., L. Sherman, and G. Broze. 1987. Absence of thrombosis in subjects with heterozygous protein C deficiency. N. Engl. J. Med. 317:991-996.

4. Koster, T., F.R. Rosendaal, E. Briet, J.M. van der Meer, L.P. Colly, P.H. Trienekens, S. Poort, P.H. Reitsma, and J.P. Vanderbroucke. 1995. Protein C deficiency in a controlled series of unselected outpatients: an infrequent but clear risk for venous thrombosis (Leiden thrombophilia study). Blood. 85:27562761.

5. Seligsohn, U., A. Berger, M. Abend, L. Rubin, D. Attias, A. Zivelin, and S.I. Rapaport. 1984. Homozygous protein C deficiency manifested by massive venous thrombosis in the newborn. N. Engl. J. Med. 310:559-562.

6. Sills, R.H., R.A. Marlar, R.R. Montgomery, G.N. Deshpande, and J.R. Humbert. 1984. Severe homozygous protein C deficiency. J. Pediatr. 105:409-413.

7. Estelles, A., I. Garcia-Plaza, A. Dasi, J. Aznar, M. Duart, G. Sanz, J.L. Perez-Requejo, F. Espana, C. Jimenez, and G. Abeledo. 1984. Severe inherited "homozygous" protein C deficiency in a newborn infant. Thromb. Haemostasis. 52:53-56.

8. Marciniak, E., H.D. Wilson, and R.A. Marlar. 1985. Neonatal purpura fulminans: a genetic disorder related to the absence of protein $\mathrm{C}$ in blood. Blood. 65:15-20.

9. Casella, J.F., F.A. Bontempo, H. Markel, J.H. Lewis, B.J. Zitelli, and T.E. Starzl. 1988. Successful treatment of homozygous protein C deficiency by hepatic transplantation. Lancet. i:435-437.

10. Minford, A.M.B., L.A. Parapia, C. Stainforth, and D. Lee. 1996. Treatment of homozygous protein $\mathrm{C}$ deficiency with subcutaneous protein $\mathrm{C}$ concentrate. Br. J. Haematol. 93:215-216.

11. Dreyfus, M., M. Masterson, M. David, G.E. Rivard, F.M. Muller, W. Kreuz, T. Beeg, A. Minford, J. Allgrove, J.D. Cohen, et al. 1995. Replacement therapy with a monoclonal antibody purified protein $\mathrm{C}$ concentrate in newborns with severe congenital protein C deficiency. Semin. Thromb. Hemostasis. 21:371-381.

12. Muller, F.M., W. Ehrenthal, G. Hafner, and D. Schranz. 1996. Purpura fulminans in severe congenital protein $\mathrm{C}$ deficiency: monitoring of treatment with protein C concentrate. Eur. J. Pediatr. 155:20-25.

13. Baliga, V., R. Thwaites, M.L. Tillyer, A., Minford, L. Parapia, and J. Allgrove. 1995. Homozygous protein C deficiency-management with protein $\mathrm{C}$ concentrate. Eur. J. Pediatr. 154:534-538.

14. Cassels-Brown, A., A.M.B. Minforn, S.L. Chatfield, and J.A. Bradbury. 1994. Ophthalmic manifestations of neonatal protein C deficiency. Br. J. Ophthalmol. 78:486-487.

15. Branson, H.E., J. Katz, R. Marble, and J.H. Griffin. 1983. Inherited protein $\mathrm{C}$ deficiency and coumarin-responsive chronic relapsing purpura fulminans in a newborn infant. Lancet. ii:1165-1168.

16. Hartman, K.R., M. Manco-Johnson, J.S. Rawlings, D.J. Bower, and R.A. Marlar. 1989. Homozygous protein C deficiency: early treatment with warfarin. Am. J. Pediatr. Hematol. Oncol. 11:395-401.

17. Yuen, P., A. Cheung, H.J. Lin, F. Ho, J. Mimuro, N. Yoshida, and N. Aoki. 1986. Purpura fulminans in a Chinese boy with congenital protein $\mathrm{C}$ deficiency. Pediatrics. 77:670-676.

18. Garcia-Plaza, I., C. Jimenez-Astorga, D. Borrego, and M.L. Marty. 1985. Coumarin prophylaxis for fulminant purpura syndrome due to homozygous protein C deficiency. Lancet. i:634-635.

19. Auberger, K. 1992. Evaluation of a new protein-C concentrate and comparison of protein-C assays in a child with congenital protein-C deficiency. Ann. Hematol. 64:146-151.

20. Conrad, J., K.A. Bauer, A. Gruber, J.H. Griffin, H.P. Schwartz, M.H. Horellou, M.M. Samama, and R.D. Rosenberg. 1993. Normalization of markers of coagulation activation with a purified protein $\mathrm{C}$ concentrate in adults with homozygous protein C deficiency. Blood. 82:1159-1164.

21. Brownlee, G.G. 1995. Prospects for gene therapy for haemophilia A and B. Br. Med. Bull. 51:91-105.

22. Thompson, A.R. 1995. Progress towards gene therapy for the hemophilias. Thromb. Hemostasis. 74:45-51.

23. Lozier, J., and K.M. Brinkhous. 1994. Gene therapy and the hemophilias. J. Am. Med. Assoc. 271:47-51.

24. Ponder, K.P. 1997. Gene delivery for systemic expression. In Gene Therapy in the Cardiovascular System. K.L. March, editor. Kluwar Academic Publishers, Norwell, MA. 395-432.
25. Connelly, S., T.A.G. Smith, G. Dhir, J.M. Gardner, M.G. Mehaffey, K.S. Zaret, A. McClelland, and M. Kaleko. 1995. In vivo gene delivery and expression of physiological levels of functional human factor VIII in mice. Hum. Gene Ther. 6:185-193.

26. Connelly, S., J. Mount, A. Mauser, J.M. Gardner, M. Kaleko, A. Mc Clelland, C.D. Lothrop. 1996. Complete short-term correction of canine hemophilia A by in vivo gene therapy. Blood. 88:3846-3853.

27. Connelly, S., J.M. Gardner, A. McClelland, and M. Kaleko. 1996. Highlevel tissue-specific expression of functional human factor VIII in mice. Hum Gene Ther. 7:183-195

28. Dai, Y., E.M. Schwartz, D. Gu, W.-W. Zhang, N. Sarvetnick, and I.M. Verma. 1995. Cellular and humoral immune responses to adenoviral vectors containing factor IX gene: tolerization of factor IX and vector antigens allows for long-term expression. Proc. Natl. Acad. Sci. USA. 92:1401-1405.

29. Kay, M.A., C.N. Landen, S.R. Rothenberg, L.A. Taylor, F. Leland, S. Wiehle, B. Fang, D. Bellinger, M. Finegold, A.R. Thompson, et al. 1994. In vivo hepatic gene therapy: complete albeit transient correction of factor IX deficiency in hemophilia B dogs. Proc. Natl. Acad. Sci. USA. 91:2353-2357.

30. Smith, T.A.G., M.G. Mehaffey, D.B. Kayda, S.M. Saunders, S. Yei, B.C. Trapneck, A. McClelland, and M. Kaleko. 1993. Adenovirus mediated expression of therapeutic plasma levels of human Factor IX in mice. Nat. Genet. 5: 397-402.

31. Walter, J., Q. You, J.N. Hagstrom, M. Sands, and K.A. High. 1996. Successful expression of human factor IX following repeat administration of an adenoviral vector in mice. Proc. Natl. Acad. Sci. USA. 93:3056-3061.

32. Perales, J.C., T. Ferkol, H. Beegen, O.D. Ratnoff, and R.W. Hanson. 1994. Gene transfer in vivo: sustained expression of genes introduced into the liver by receptor-targeted uptake. Proc. Natl. Acad. Sci. USA. 91:4086-4090.

33. Wang, J.-M., H. Zheng, M. Blaivas, and K. Kurachi. 1997. Persistent systemic production of human Factor IX in mice by skeletal myoblast-mediated gene transfer: feasibility of repeat application to obtain therapeutic levels. Blood. 90:1075-1082.

34. Kay, M.A., S. Rothenberg, D.A. Bellinger, F. Leland, C. Tomin, M.S Reed, K.M. Brinkhous, and S.L.C. Woo. 1993. In vivo gene therapy of hemophilia B: sustained partial correction in factor IX deficient dogs. Science. 266: 117-119.

35. Dai, Y., M. Roman, R.K. Naviaux, and I.M. Verma. 1992. Gene therapy via primary myoblasts: long-term expression of factor IX protein following transplantation in vivo. Proc. Natl. Acad. Sci. USA. 89:10892-10895.

36. Le, M.T., T. Okuyama, S.-R. Cai, S.C. Kennedy, W. Bowling, M.W. Flye, and K.P. Ponder. 1997. Therapeutic levels of functional human factor X in rats after retroviral-mediated hepatic gene therapy. Blood. 89:1254-1259.

37. Herzog, R.W., J.N. Hagstrom, S.H. Kung, S.J. Tai, J.M. Wilson, K.J Fisher, and K.A. High. 1997. Stable gene transfer and expression of human blood coagulation factor IX after intramuscular injection of recombinant adeno-associated virus. Proc. Natl. Acad. Sci. USA. 94:5804-5809.

38. Snyder, R.O., C.H. Miao, G.A. Patijn, S.K. Spratt, O. Danos, D. Nagy, A.M. Gown, B. Winther, L. Meuse, L.K. Cohen, et al. 1997. Persistent and therapeutic concentrations of human factor IX in mice after hepatic gene transfer of recombinant AAV vectors. Nat. Genet. 16:270-275.

39. Foster, D., and E.W. Davie. 1984. Characterization of a cDNA coding for human protein C. Proc. Natl. Acad. Sci. USA. 81:4766-4770.

40. Okuyama, T., R.M. Huber, W. Bowling, R. Pearline, S.C. Kennedy, M.W. Flye, and K.P. Ponder. 1996. Liver-directed gene therapy: a retroviral vector with a complete LTR and the ApoE enhancer- $\alpha_{1}$-antitrypsin promoter dramatically increases expression of human $\alpha_{1}$-antitrypsin in vivo. Hum. Gene Ther. 5:637-645.

41. Miller, A.D., and G.J. Rosman. 1989. Improved retroviral vectors for gene transfer and expression. Biotechniques. 7:980-990.

42. Hafenrichter, D.G., S.D. Rettinger, S.C. Kennedy, X. Wu, M.W. Flye, and K.P. Ponder. 1994. Quantitative evaluation of liver-specific promoters from retroviral vectors after in vivo transduction of hepatocytes. Blood. 84:3394 3404 .

43. Markowitz, D., S. Goff, and A. Bank. 1988. Construction and use of a safe and efficient amphotropic packaging cell line. Virology. 167:400-409.

44. Jainchill, J.L., S.A. Aaronson, and G.J. Todoro. 1969. Murine sarcoma and leukemia viruses: assay using clonal lines of contact inhibited mouse cells. J. Virol. 4:549-553.

45. Rettinger, S.D., S.C. Kennedy, X. Wu, D. Hafenrichter, M.W. Flye, and K.P. Ponder. 1994. Liver-directed gene therapy: Quantitative evaluation of promoter elements using in vivo retroviral transduction. Proc. Natl. Acad. Sci. USA. 91:1460-1464.

46. Soriano, P., C. Montgomery, R. Geske, and A. Bradley. 1991. Targeted disruption of the c-src protooncogene leads to osteopetrosis in mice. Cell. 64: 693-702.

47. Harlow, E., and D. Lane. 1988. Immunoassays. In Antibodies: A Laboratory Manual. Cold Spring Harbor Press, Cold Spring Harbor, NY. 553-612.

48. Kotani, H., P.B. Newton, S. Zhang, Y.L. Chiang, E. Otto, L. Weaver, R.M. Blaese, W.F. Anderson, and G.J. McGarrity. 1994. Improved methods of retroviral vector transduction and production for gene therapy. Hum. Gene Ther. 5:19-28.

49. Sambrook, J., E.F. Fritsch, and T. Maniatas. 1989. Molecular Cloning: A 
Laboratory Manual, Cold Spring Harbor Laboratory Press, Cold Spring Harbor, NY. 7.71-7.78, 9.16-9.21, 10.13-10.37, and 18.47-18.59.

50. Sweetser, D.A., E.H. Birkenmeier, I.J. Klisek, S. Zollman, R.S. Spark, A.J. Mohandes, A.J. Lusis, and J.I. Gordon. 1987. The human and rodent intestinal fatty acid binding protein genes. A comparative analysis of their structure, expression, and linkage relationships. J. Biol. Chem. 262:16060-16071.

51. Kozak, M. 1991. Structural features in eukaryotic mRNAs that modulate the initiation of translation. J. Biol. Chem. 266:19867-19870.

52. Bowles, N.E., R.C. Eisensmith, R. Mohuidden, M. Pyron, and S.L.C. Woo. 1996. A simple and efficient method for the concentration and purification of recombinant retrovirus for increases hepatocyte transduction in vivo. Hum. Gene Ther. 7:1735-1742.

53. Katsuura, Y., T. Mochizuki, M. Tamura, S. Hoshide, M. Kiyoki, T. Nakagaki, and S. Miyamoto. 1996. Species specificity of anticoagulant activity of activated human protein C. Thromb. Res. 82:146-157.

54. Suzuki, K., Y. Deyashiki, J. Nishioka, and K. Toma. 1989. Protein C inhibitor: structure and function. Thromb. Haemostasis. 61:337-342.

55. Espana, F., V. Vicente, D. Tabernero, I. Scharrer, and J.H. Griffen. 1990. Determination of plasma protein C inhibitor and of two activated protein $\mathrm{C}$-inhibitor complexes in normals and in patients with intravascular coagulation and thrombotic disease. Thromb. Res. 59:593-608.

56. Van der Meer, F.J.M., N.H. van Tilberg, A. Van Wijngaarden, I.K. van der Linden, E. Briet, and R.M. Bertina. 1989. A second plasma inhibitor of activated protein C: $\alpha_{1}$-antitrypsin. Thromb. Haemostasis. 62:756-762.

57. Sharon, C., M.C. Tirindelli, P.M. Mannucci, A. Tripodi, G. Mariani, and A. Bianchi. 1986. Homozygous protein C deficiency with moderately severe clinical symptoms. Thromb. Res. 41:483-488.

58. Aiach, M., S. Gandrille, and J. Emmerich. 1995. A review of mutations causing deficiencies of antithrombin, protein C, and protein S. Thromb. Haemostasis. 74:81-89.

59. Pescatore, P., H.M. Horellou, J. Conard, M. Piffoux, P. Van Dreden, A. Ruskone-Fourmestraux, and M. Samama. 1993. Problems of oral anticoagulation in an adult with homozygous protein $\mathrm{C}$ deficiency and late onset of thrombosis. Thromb. Haemostasis. 69:311-315.

60. Mohanty, D., H.A. Hassan, P. Neglan, B. Elkof, and K.C. Das. 1995. Protein C deficiency in Kuwait. J. Lab. Clin. Med. 126:373-376.

61. Jalbert, L.R., E.D. Rosen, P. Carmeliet, F.J. Castellino, and D. Collen. 1996. Characterization of the anticoagulant protein $\mathrm{C}$ by targeted inactivation in mice. Blood. 90:258a. (Abstr.)

62. Garver, R.I., A. Chytil, S. Karlsson, G.A. Fells, M.L. Brantly, M. Courtney, P.W. Kantoff, A.W. Nienhuis, W.F. Anderson, and R.G. Chrystal. 1987. Production of glycosylated physiologically normal human $\alpha_{1}$-antitrypsin by mouse fibroblasts modified by insertion of a human $\alpha_{1}$-antitrypsin cDNA using a retroviral vector. Proc. Natl. Acad. Sci. USA. 84:1050-1054.

63. St. Louis, D., and I.M. Verma. 1988. An alternative approach to somatic cell gene therapy. Proc. Natl. Acad. Sci. USA. 85:3150-3154.
64. Yao, S.-N., and K. Kurachi. 1992. Expression of human factor IX in mice after injection of genetically modified myoblasts. Proc. Natl. Acad. Sci. USA. 89:3357-3361.

65. Berson, S.A., R.S. Yalow, A. Bauman, M.A. Rothschild, and K. Newerly. 1956. Insulin- $\mathrm{I}^{131}$ metabolism in human subjects: demonstration of insulin binding globulin in the circulation of insulin treated subjects. J. Clin. Invest. 35: 170-190.

66. Prout, T.E., and R.B. Katims. 1959. The effect of insulin-binding serum globulin on insulin requirements. Diabetes. 8:425-431.

67. McAdams, G.B., K.R. Knox, D.S. Wilcox, and R. Jensen. 1967. The initial rapid-phase disappearance of intravenous radioinsulin in diabetes. J. Nucl. Med. 8:173-178.

68. Dixon, K., P.D. Exon, and J.M. Malins. 1975. Insulin antibodies and the control of diabetes. Q. J. Med. 176:543-553.

69. Takano, K., K. Shizume, N. Hizuka, A. Okuno, T. Umino, Y. Kobayashi, S. Kusano, H. Nakajima, M. Irie, and I. Hibi. 1986. Treatment of pituitary dwarfism with methionyl human growth hormone in Japan. Endocrinol. Jpn. 33:589-596.

70. Batlle, J., E. Gomez, E. Rendal, J. Torea, E. Loures, M. Couselo, P. Vila, C. Sedano, X. Tusell, M. Magallon, et al. 1996. Antibodies to factor VIII in plasma of patients with hemophilia A and normal subjects. Ann. Hematol. 72: 321-326.

71. Richards, S.M., T.A. Olson, and J.M. McPherson. 1993. Antibody response in patients with Gaucher disease after repeated infusion with macrophage-targeted glucocerebrosidase. Blood. 82:1402-1409.

72. Pastores, G.M., A.R. Sibille, and G.A. Grabowski. 1993. Enzyme therapy in Gaucher Disease type 1: dosage efficacy and adverse effects in 33 patients treated for 6 to 24 months. Blood. 82:408-416.

73. Ponce, E., J. Moskovitz, and G. Grabowski. 1997. Enzyme therapy in Gaucher disease type 1: effect of neutralizing antibodies to acid beta-glucuronidase. Blood. 90:43-48.

74. Bowling, W.M., S.C. Kennedy, S.-R. Cai, J.R. Duncan, M.W. Flye, and K.P. Ponder. 1996. Portal branch occlusion safely facilitates in vivo retrovira vector transduction of rat liver. Hum. Gene Ther. 7:2113-2121.

75. Duncan, J.R., M. Hicks, S.-R. Cai, E.M. Brunt, and K.P. Ponder. 1998. Embolization of portal vein branches induces hepatocyte replication in swine. A potential step in hepatic gene therapy. Radiology. In press.

76. Bosch, A., P.B. McCray, S.M.W. Chang, T.R. Ulish, W.S. Simonet, D.J. Jolly, and B.L. Davidson. 1996. Proliferation induced by keratinocyte growth factor enhances in vivo retroviral vector-mediated gene transfer to mouse hepatocytes. J. Clin. Invest. 98:2683-2687.

77. Patijn, G.A., A. Lieber, D.B. Schwalter, R. Schwall, and M.A. Kay. 1998. Hepatocyte growth factor induces proliferation in vivo and allows for efficient retroviral vector transfer in mice. In Keystone Meeting: Molecular and Cellular Biology of Gene Therapy 52. E.G. Nobel and I. Verma, editors. 